\title{
Spatial Distribution and Contamination Assessment of Heavy Metals in Surface Sediments of the Caofeidian Adjacent Sea after the Land Reclamation, Bohai Bay
}

\author{
He Zhu, ${ }^{1,2,3}$ Haijian Bing, ${ }^{1}$ Huapeng $Y i,{ }^{2}$ Yanhong $W u\left(\mathbb{D},{ }^{1}\right.$ and Zhigao Sun $\mathbb{D}^{4}$ \\ ${ }^{1}$ Key Laboratory of Mountain Surface Processes and Ecological Regulation, Institute of Mountain Hazards and Environment, \\ Chinese Academy of Sciences, Chengdu 610041, China \\ ${ }^{2}$ School of Resources and Environmental Engineering, Ludong University, Yantai 264025, China \\ ${ }^{3}$ University of Chinese Academy of Sciences, Beijing 100049, China \\ ${ }^{4}$ Key Laboratory of Humid Subtropical Eco-Geographical Process (Fujian Normal University), \\ Ministry of Education, Fuzhou 350007, China \\ Correspondence should be addressed to Yanhong Wu; yanhong_wu@yeah.net and Zhigao Sun; zhigaosun@163.com
}

Received 5 January 2018; Accepted 12 March 2018; Published 22 April 2018

Academic Editor: Ana Moldes

Copyright @ $2018 \mathrm{He}$ Zhu et al. This is an open access article distributed under the Creative Commons Attribution License, which permits unrestricted use, distribution, and reproduction in any medium, provided the original work is properly cited.

Land reclamation can significantly influence spatial distribution of heavy metals in inshore sediments. In this study, the distribution and contamination of heavy metals $(\mathrm{Cd}, \mathrm{Cr}, \mathrm{Cu}, \mathrm{Ni}, \mathrm{Pb}$, and $\mathrm{Zn})$ in inshore sediments of Bohai Bay were investigated after the land reclamation of Caofeidian. The results showed that the concentrations of $\mathrm{Cd}, \mathrm{Cr}, \mathrm{Cu}, \mathrm{Ni}, \mathrm{Pb}$, and $\mathrm{Zn}$ in the sediments were $0.20-0.65$, $27.16-115.70,11.14-39.00,17.37-65.90,15.08-24.06$, and $41.64-139.56 \mathrm{mg} / \mathrm{kg}$, respectively. These metal concentrations were generally higher in the area of Caofeidian than in other Chinese bays and estuaries. Spatially, the concentrations of $\mathrm{Cd}, \mathrm{Cr}, \mathrm{Cu}, \mathrm{Ni}$, and $\mathrm{Zn}$ were markedly lower in the sediments close to Caofeidian compared with other regions, whereas the concentrations of $\mathrm{Pb}$ showed an opposite case. Hydrodynamic conditions after the land reclamation were the major factor influencing the distribution of heavy metals in the sediments. Grain sizes dominated the distribution of $\mathrm{Cu}$ and $\mathrm{Zn}$, and organic matters and Fe/Mn oxides/hydroxides also determined the distribution of the heavy metals. Multiple contamination indices showed that the inshore sediments were moderately to highly contaminated by $\mathrm{Cd}$ and slightly contaminated by other heavy metals. Similarly, Cd showed a high potential ecorisk in the sediments, and other metals were in the low level. Chromium contributed to higher exposure toxicity than other metals by the toxicity unit and toxic risk index. The results of this study indicate that after the land reclamation of Caofeidian the contamination and ecorisk of heavy metals in the sediments markedly decreased in the stronger hydrodynamic areas.

\section{Introduction}

Heavy metal contamination is a major issue in marine environment due to the toxicity, persistence, nonbiodegradability, and bioaccumulation [1-3]. After entering food chain, they can cause potential threat to human beings and other organisms [4]. In aquatic systems, sediments are the main sink of various contaminants discharged from industrial and agricultural processes [5-7], and they are regarded as an effective archive recording heavy metal contamination [2, $8,9]$. To date, a large number of studies have reported the accumulation of heavy metals in the sediments of aquatic ecosystems [3,10-13]. The main reason is that once the conditions of sedimentary environment change, heavy metals are apt to release into water from the sediments [14-16]. Therefore, it is necessary to understand the characteristics of heavy metals in aquatic sediments and assess their contamination states.

The coastal zone is one of the most frequent areas disturbed by human activities through plant and port construction, land reclamation, and tourism [1, 17-19]. Human activities, on the one hand, will increase the loadings of heavy metals in the aquatic system through direct industrial discharge, city sewage, domestic runoff, and so forth [20-22]; 
on the other hand, they can change pristine sedimentary environment which may contribute to the release of heavy metals from sediments. Among these human activities, land reclamation engineering is significant to influence aquatic environment [23-25]. It not only alters the hydrodynamic conditions surrounding the land but also may increase inputs of heavy metals through sewage discharge and shipping after the engineering. The distribution of heavy metals and their controlling factors in sediments of coastal zone still need to be explored under the land reclamation.

The toxicity of heavy metals is the priority in aquatic ecosystems [26-28]. In order to control the contamination of marine sediments and protect marine biological resources, China, USA, Canada, and other countries have established the standard of marine sediment quality for heavy metals [29, 30]. Meanwhile, various methods have been applied to assess the contamination and ecorisk of heavy metals in sediments, including enrichment factor [31, 32], index of geoaccumulation [33, 34], toxic units and toxic risk index [35], and potential ecorisk index $[22,36]$. However, each method has its limitation or specialization, and thus it is necessary to use multiple methods in order to accurately obtain the contamination and ecorisk states of heavy metals in sediments $[11,15]$.

Bohai Bay is located in the western Bohai Sea. Due to the weak exchange capacity of the water in Bohai Bay, the contaminants from surrounding industrial cities are not easy to spread. Recently, the Bohai Bay has been regarded as a main region of contaminant accumulation, especially in the sediments [37-39]. These studies investigated the distribution of heavy metals and assessed their contamination, and the results showed that human activates increased the accumulation of heavy metals in the sediments of Bohai Bay [25, 40]. However, most of the studies were conducted in the areas of Tianjin Port $[41,42]$, whereas there are very few reports about the distribution and contamination states of heavy metals in the sediments of northern Bohai Bay. This limits our understanding of heavy metal distribution in the entire area of Bohai Bay. More importantly, the large-scale reclamation project has been finished in Caofeidian for few years. This engineering certainly influences the environment conditions of inshore and adjacent marine area. Whether the land reclamation causes significant difference of the distribution and contamination of heavy metals in the sediments around Caofeidian deserves to be explored.

In this study, the surface sediments in the coastal areas of Caofeidian were collected to analyze the concentrations of heavy metals ( $\mathrm{Cd}, \mathrm{Cr}, \mathrm{Cu}, \mathrm{Ni}, \mathrm{Pb}$, and $\mathrm{Zn}$ ). The main objectives are (1) to investigate distribution characteristics of these heavy metals in the sediments, (2) to explore the possible controlling factors for their spatial distributions, and (3) to assess the contamination and potential ecological risk of the heavy metals. This is the first time to reveal the distribution of heavy metal contamination in the surface sediments of Caofeidian after the land reclamation project.

\section{Materials and Methods}

2.1. Study Area. Caofeidian is located in the northern Bohai Bay $\left(38^{\circ} 58^{\prime} 52^{\prime \prime}-38^{\circ} 54^{\prime} 42^{\prime \prime} \mathrm{N}, 118^{\circ} 33^{\prime} 36^{\prime \prime}-118^{\circ} 30^{\prime} 03^{\prime \prime} \mathrm{E}\right.$,
Figure 1). It is surrounded by Hebei province and Tianjin City on the north and west, respectively. Hai River, Luan River, Yongding River, and other small rivers discharge water into the inshore and adjacent areas of Caofeidian. Laolonggou, located in the eastern Caofeidian, is the ancient Luanhe River with previous tidal channel [43]. The study area has complex geomorphic types with a large number of sandbanks distributed in this area. The average water depth around the Caofeidian is approximately $30 \mathrm{~m}$ (Figure 1), and the deepest site (B20) reaches approximately $36 \mathrm{~m}$ due to the strong hydrodynamic conditions. Due to the presence of sandbanks and deep water depth, a large-scale reclamation project has been implemented in Caofeidian in 2003, and the project is basically finished in 2011. Now it becomes one of the busiest ports in the Bohai Sea with a cargo throughput of $>5$ billion tons in 2014 [28].

2.2. Sample Collection. The sampling was carried out in August 2014. Twenty-two sampling sites in the inshore and adjacent areas of Caofeidian were selected to collect the surface sediments (Figure 1). At each site, the sediment samples were collected using a gravity sampler, and then the surface sediments $(0-5 \mathrm{~cm})$ were sliced by a plastic spatula in the field. The samples were put in polyethylene bags and stored at $-20^{\circ} \mathrm{C}$ for further analysis. In laboratory, the sediment samples were freeze-dried. The samples for the grain size analysis passed through $2 \mathrm{~mm}$ sieves, and those for the analysis of total organic carbon (TOC) and elements passed through 100-mesh Nylon screen.

2.3. Chemical Analysis. The grain sizes of the surface sediments were measured by a Mastersizer-2000 laser particle size analyzer (Malvern, UK) after removal of organic matters with $30 \% \mathrm{H}_{2} \mathrm{O}_{2}$ with the dispersion of sodium hexametaphosphate. Three classes of grain sizes were divided into clay $(<4 \mu \mathrm{m})$, silt $(4-63 \mu \mathrm{m})$, and sand $(>63 \mu \mathrm{m})$. The concentrations of TOC in the sediments were measured by subtracting the inorganic carbon from the total carbon, which was determined by a Shimadzu TOC-VCPH/SSM-5000A and Elementar vario MACRO cube CHNS analyzer, respectively.

The concentrations of metals in the sediments were measured according to the method of Gao and Chen [23]. Briefly, approximately $0.1 \mathrm{~g}$ samples were digested in Teflon Vessel with the mixed concentrated acids of $\mathrm{HF}-\mathrm{HNO}_{3}-\mathrm{HClO}_{4}$ $(5: 2: 1)$ and then heated $\left(140-150^{\circ} \mathrm{C}\right)$ to dryness. The residue was digested with $\mathrm{HNO}_{3}$ again. At the end, the extraction was diluted to $50 \mathrm{~mL}$ volume. The concentrations of $\mathrm{Fe}$ and Mn were measured by an inductively coupled plasma atomic emission spectrometer (ICP-AES), and those of $\mathrm{Cd}, \mathrm{Cr}, \mathrm{Cu}$, $\mathrm{Ni}, \mathrm{Pb}$, and $\mathrm{Zn}$ were detected by an inductively coupled plasma mass spectroscopy (ICP-MS). Quality assurance and control were evaluated using duplicates, blanks, and standard reference materials (GBW 07401) from the National Research Center for Standards in China. According to the measurement of the repeated samples and reference materials, the relative standard deviation was below 3\% for ICP-AES and below 5\% for ICP-MS, respectively. The recovery of the reference materials was $95.3 \%-107.3 \%$. 


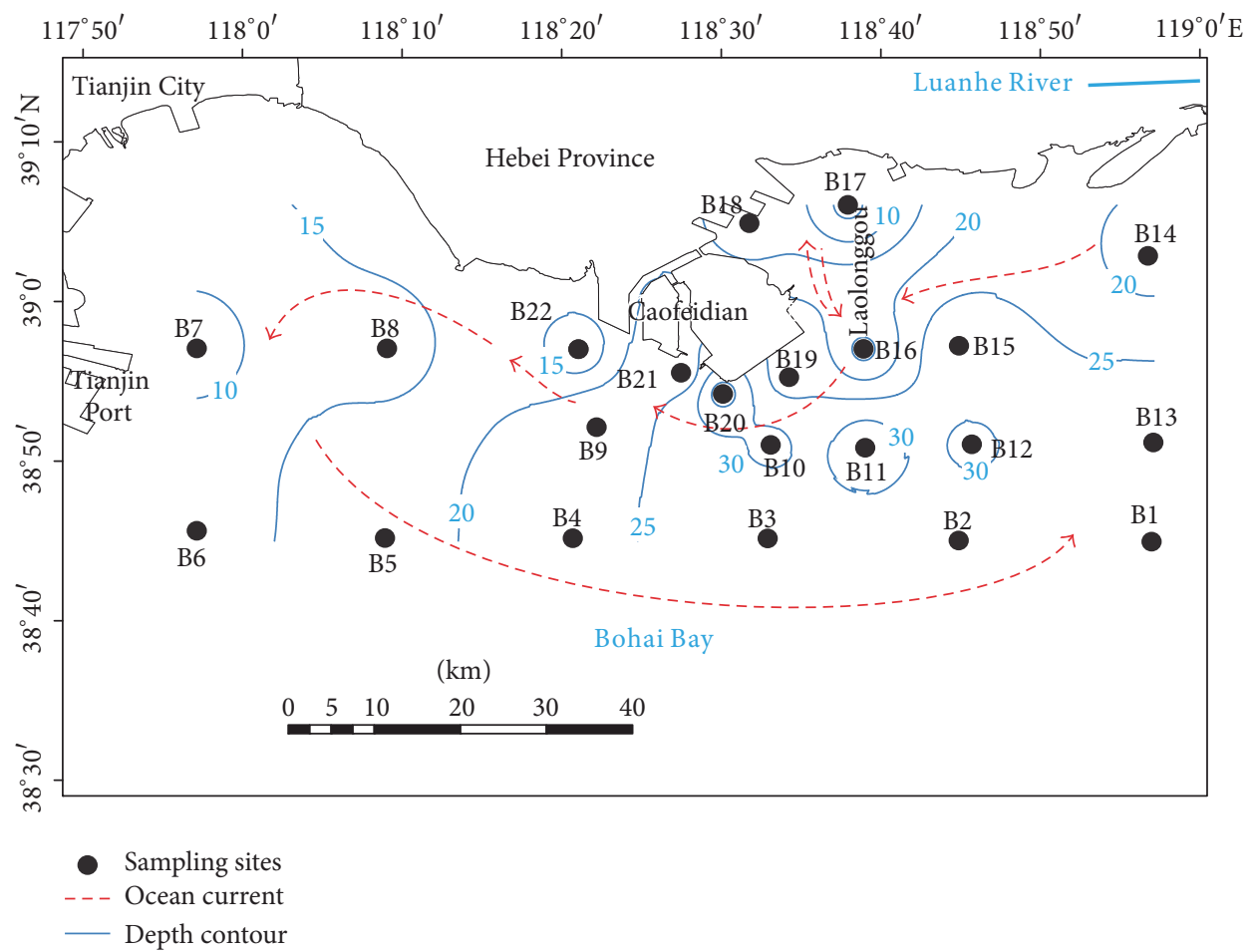

Figure 1: The location of the study area and the sampling sites in the Bohai Bay.

\subsection{Calculation of Contamination and Ecorisk Indices}

2.4.1. Enrichment Factors (EFs). The EFs of heavy metals in the sediments are calculated as follows [11]:

$$
\mathrm{EF}=\frac{(\mathrm{Me} / \mathrm{Fe})_{\text {sample }}}{(\mathrm{Me} / \mathrm{Fe})_{\text {background }}},
$$

where $(\mathrm{Me} / \mathrm{Fe})_{\text {sample }}$ is the concentration ratio of a metal to $\mathrm{Fe}$ in a sample and $(\mathrm{Me} / \mathrm{Fe})_{\text {background }}$ is the corresponding ratio in the background.

2.4.2. Geoaccumulation Index. The geoaccumulation index $\left(I_{\text {geo }}\right)$ is another indicator used to assess the contamination of heavy metals in sediments [33]:

$$
I_{\text {geo }}=\log _{2}\left(\frac{C_{n}}{k \times B_{n}}\right) \text {, }
$$

where $C_{n}$ is the concentration of a metal measured in a sample, $B_{n}$ is the geochemical background of the metal, and $k$ is a background matrix correction factor (1.5) due to lithogenic effects [31]. The contamination classes of $I_{\text {geo }}$ are classified as $I_{\text {geo }} \leq 0$, uncontaminated; $0<I_{\text {geo }} \leq 1$, uncontaminated to moderately contaminated; $1<I_{\text {geo }} \leq 2$, moderately contaminated; $2<I_{\text {geo }} \leq 3$, moderately to heavily contaminated; $3<$ $I_{\text {geo }} \leq 4$, heavily contaminated; $4<I_{\text {geo }} \leq 5$, heavily to extremely contaminated; $I_{\text {geo }}>5$, extremely contaminated [33].
2.4.3. Potential Ecorisk Index $\left(E_{r}^{i}\right)$. The potential ecorisk index is commonly used to assess the ecorisk of heavy metals in sediments [36]:

$$
\begin{aligned}
& E_{r}^{i}=T_{r}^{i} * \frac{C_{o}^{i}}{C_{n}^{i}}, \\
& \mathrm{RI}=\sum_{i=1}^{n} E_{r}^{i},
\end{aligned}
$$

where $E_{r}^{i}$ is the potential ecorisk index, $T_{r}^{i}$ is the toxic response coefficient of a given metal, $C_{o}^{i}$ is the concentration of a metal measured in a sample, and $C_{n}^{i}$ is its geochemical background. The toxic response coefficient of $\mathrm{Cd}, \mathrm{Cr}, \mathrm{Cu}, \mathrm{Ni}, \mathrm{Pb}$, and $\mathrm{Zn}$ is 30, 2, 5, 2, 5, and 1, respectively. The potential ecorisk level of heavy metals in sediments is classified as $E_{r}^{i} \leq 40$, low; $40<E_{r}^{i} \leq 80$, moderate; $80<E_{r}^{i} \leq 160$, high; $160<E_{r}^{i} \leq 320$, very high; $E_{r}^{i}>320$, extremely high. The risk classes of RI are classified as $<150$, low risk; 150-300, moderate risk; 300-600, considerable risk; $\geq 600$, disastrous risk [39].

2.4.4. The Toxic Units (TUs) and Toxic Risk Index (TRI). The TU defined by Pedersen et al. [48] is the ratio of a metal concentration to the probable effects level (PEL). $\sum$ TUs is the sum of the ratio of six heavy metals to PEL. These indices can assess heavy metal toxicity relative to the standard. $\sum$ TUs < 4 represents nontoxicity and $\sum$ TUs $>6$ represents acute toxicity: 
TABLE 1: The concentrations of heavy metals and physiochemical properties in the sediments.

\begin{tabular}{lcccc}
\hline & Unit & Max & Min & Average \\
\hline $\mathrm{Cd}$ & $\mathrm{mg} / \mathrm{kg}$ & 0.65 & 0.20 & 0.34 \\
$\mathrm{Cr}$ & $\mathrm{mg} / \mathrm{kg}$ & 115.70 & 27.16 & 11.14 \\
$\mathrm{Cu}$ & $\mathrm{mg} / \mathrm{kg}$ & 39.00 & 17.37 & 28.82 \\
$\mathrm{Ni}$ & $\mathrm{mg} / \mathrm{kg}$ & 65.90 & 15.08 & 41.35 \\
$\mathrm{~Pb}$ & $\mathrm{mg} / \mathrm{kg}$ & 24.06 & 41.64 & 21.02 \\
$\mathrm{Zn}$ & $\mathrm{mg} / \mathrm{kg}$ & 139.56 & 20.72 & 88.64 \\
$\mathrm{Fe}$ & $\mathrm{mg} / \mathrm{g}$ & 50.02 & 302.49 & 37.09 \\
$\mathrm{Mn}$ & $\mathrm{mg} / \mathrm{kg}$ & 868.15 & 7.67 & 571.33 \\
$\mathrm{Clay}$ & $\%$ & 17.91 & 37.71 & 13.05 \\
$\mathrm{Slit}$ & $\%$ & 80.52 & 3.29 & 63.42 \\
Sand & $\%$ & 54.62 & 0.26 & 23.53 \\
TOC & $\%$ & 0.95 & & 0.72 \\
\hline
\end{tabular}

$$
\sum \mathrm{TUs}=\sum_{i=1}^{n} \frac{C_{s}^{i}}{C_{\mathrm{PEL}}^{i}} .
$$

The TRI is used to assess the integrated toxic risk based on the threshold effect level (TEL) and PEL of heavy metals [26]:

$$
\mathrm{TRI}=\sqrt{\frac{\left(C_{s}^{i} / C_{\mathrm{TEL}}^{i}\right)^{2}+\left(C_{s}^{i} / C_{\mathrm{PEL}}^{i}\right)^{2}}{2}},
$$

where $C_{s}^{i}$ is the concentration of a metal measured in the sample, and $C_{\mathrm{TEL}}^{i}$ and $C_{\mathrm{PEL}}^{i}$ are the TEL and PEL of the metal, respectively. The TRI can be classified as no toxic risk (TRI < $5)$, low toxic risk $(5 \leq \mathrm{TRI}<10)$, moderate toxic risk $(10 \leq \mathrm{TRI}$ $<15)$, considerable toxic risk $(15 \leq \mathrm{TRI}<20)$, and very high toxic risk (TRI $\geq 20$ ).

2.5. Statistical Analysis. Pearson correlation analysis was applied to establish the relationships between heavy metals and sediment physiochemical properties by the software package SPSS 16.0 for Windows. The spatial distribution characteristics of heavy metals and physiochemical properties in the sediments were performed by the software ArcGIS 10.2 with the method of inverse distance weighted (IDW).

\section{Results and Discussion}

3.1. Sediment Physiochemical Properties. The composition of grain sizes showed the order of silt (37.71-80.41\%, average: $63.42 \%)>$ sand $(3.29-54.62 \%, 23.53 \%)>$ clay $(7.39-17.91 \%$, $13.05 \%$ ) (Table 1). Spatially, clay and silt presented a similar distribution pattern (Figure 2). The lower contents of silt and clay were observed in the Laolonggou, compared with other regions, whereas the higher contents occurred in the western Caofeidian and the central Bohai Bay. The spatial distribution of sand generally showed the opposite case to that of clay and silt.

The concentrations of TOC varied between $0.26 \%$ and $0.95 \%$ with the average of $0.72 \%$ (Table 1 ). The concentrations of TOC were relatively lower in the eastern Caofeidian than in other areas, and the highest was observed in the central Bohai Bay (Figure 2). The concentrations of Fe and Mn varied between 50.02 and 20.72 (average: 37.09, g/kg) and between 302.49 and 868.15 (average: 571.33, $\mathrm{mg} / \mathrm{kg}$ ), respectively (Table 1). The concentrations of Fe and Mn were lower in the eastern and western Caofeidian than in the central Bohai Bay (Figure 2).

3.2. The Concentrations of Heavy Metals in the Sediments. The concentrations of heavy metals in the sediments are presented in Table 1. Specifically, the concentrations $(\mathrm{mg} / \mathrm{kg})$ varied between 0.20 and 0.65 (average: 0.36 ) for $\mathrm{Cd}$, between 27.16 and 115.70 (78.64) for Cr, between 11.14 and 39.00 (29.07) for $\mathrm{Cu}$, between 17.37 and 65.90 (41.35) for $\mathrm{Ni}$, between 15.08 and 24.06 (21.11) for $\mathrm{Pb}$, and between 41.64 and 139.56 (89.60) for $\mathrm{Zn}$. The concentrations of all the heavy metals in the sediments exceeded their background standards in the upper continental crust (Table 2). Compared with some bays and estuaries in China, the Cd concentrations in the inshore sediments of Caofeidian were higher except for the Liaodong Bay (Table 2). For other heavy metals, their concentrations in our study area were generally higher than those in other estuaries.

The distribution of heavy metals in the sediments displayed significantly different spatial patterns (Figure 3 ). The concentrations of $\mathrm{Cd}$ in the sediments were generally lower in the surrounding areas of Caofeidian relative to the southeastern and southwestern area. The similar distribution of $\mathrm{Cr}$, $\mathrm{Cu}, \mathrm{Ni}$, and $\mathrm{Zn}$ was observed spatially, and their lower concentrations occurred in the eastern and western Caofeidian compared with other areas. The distribution of $\mathrm{Pb}$ in the sediments showed that its concentrations were markedly higher in the inshore areas of Caofeidian and the central Bohai Bay compared with the western study area.

3.3. Factors Controlling the Distribution of Heavy Metals. Hydrodynamic conditions are a main factor influencing the distribution of heavy metals in the sediments. The concentrations of heavy metals except for $\mathrm{Pb}$ were higher in the central Baohai Bay compared with those in the western and eastern Caofeidian (Figure 3). The oceanic current in the northern 

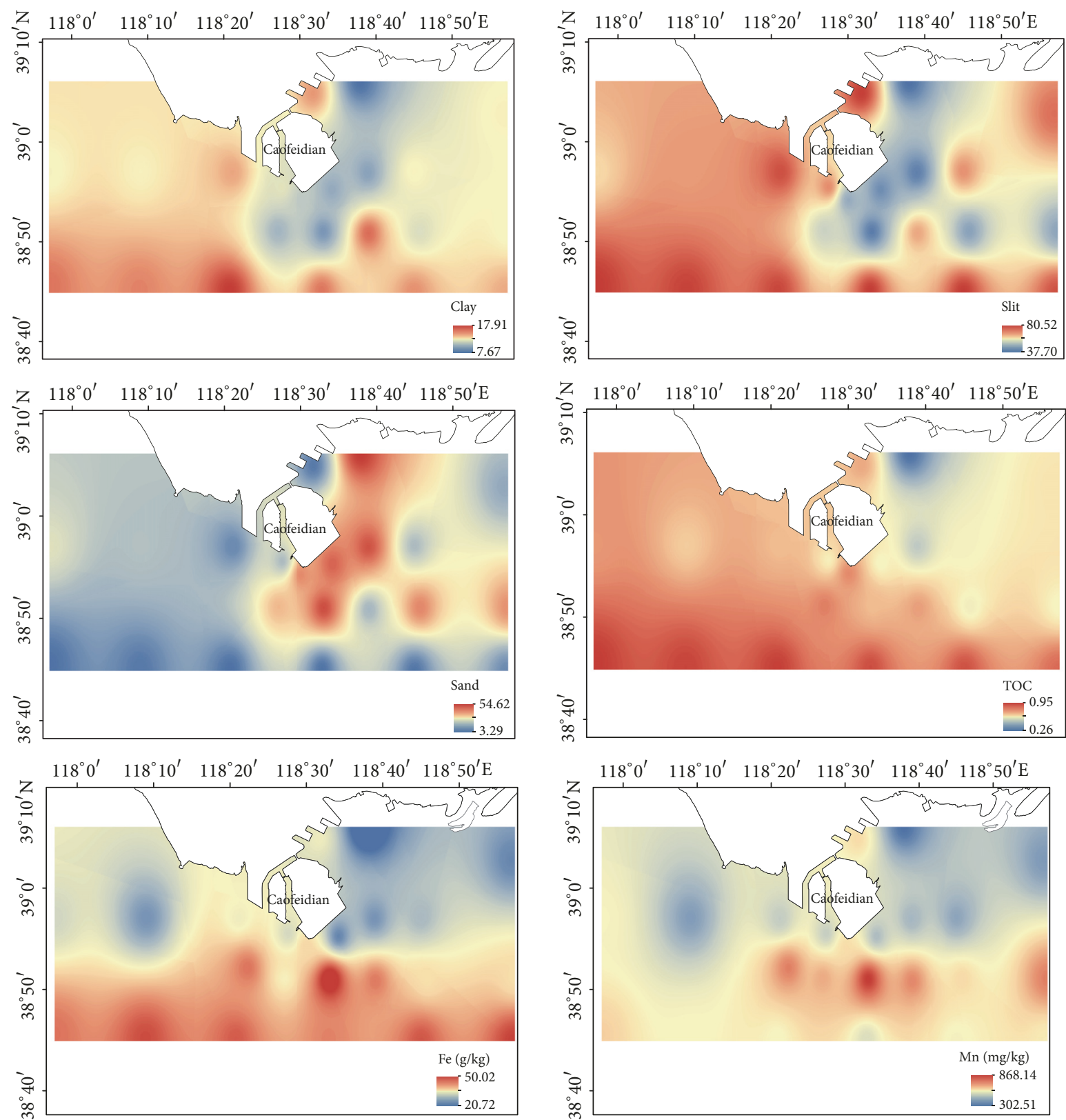

FIgURE 2: The spatial distribution of grain sizes, TOC, Fe, and Mn in the sediments.

Bohai Bay has been observed flowing from east to west [49]. The land reclamation of Caofeidian blocks the oceanic current which should have passed through the Caofeidian area before the reclamation project. The channel of the oceanic current becomes narrow in the northern Bohai Bay, resulting in much erosion in the Laolonggou area (Figure 1), and then the current enters the cape of Caofeidian [24, 49]. The variation of the hydrodynamic conditions around the Caofeidian cape led to the fine particles washed out and hard to deposit in the eastern area and the cape of Caofeidian [43]. This was a major reason for the low distribution of heavy metals in the eastern area and the cape of Caofeidian. With the flow of the oceanic current forward, the hydrodynamic conditions became weakened which favored the sediment deposition and then the heavy metal accumulation in the western Caofeidian.

The results of Pearson correlation analysis showed that $\mathrm{Cu}$ and $\mathrm{Zn}$ correlated significantly with clay and silt $(p<0.05$, Table 3). The concentrations of heavy metals in sediments increase with decreasing particle because the fine-grained sediments tend to adsorb much more heavy metals due to their high specific surface area $[50,51]$. The fine particles were markedly observed in the western Caofeidian and the central Bohai Bay compared with the Laolongou and the cape of Caofeidian (Figure 2). Lu et al. (2009) also reported that the grain sizes of the sediments in the study area decreased from the eastern to western Caofeidian [24]. The tidal current induced the runoff and sorting of the sediments 


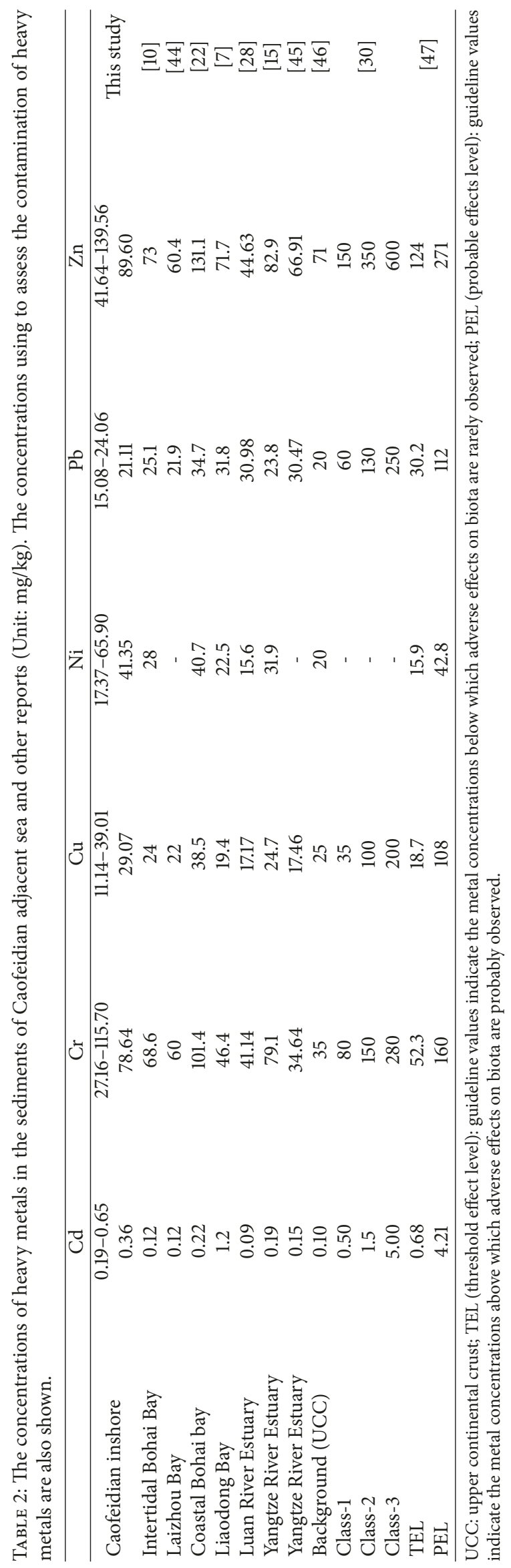



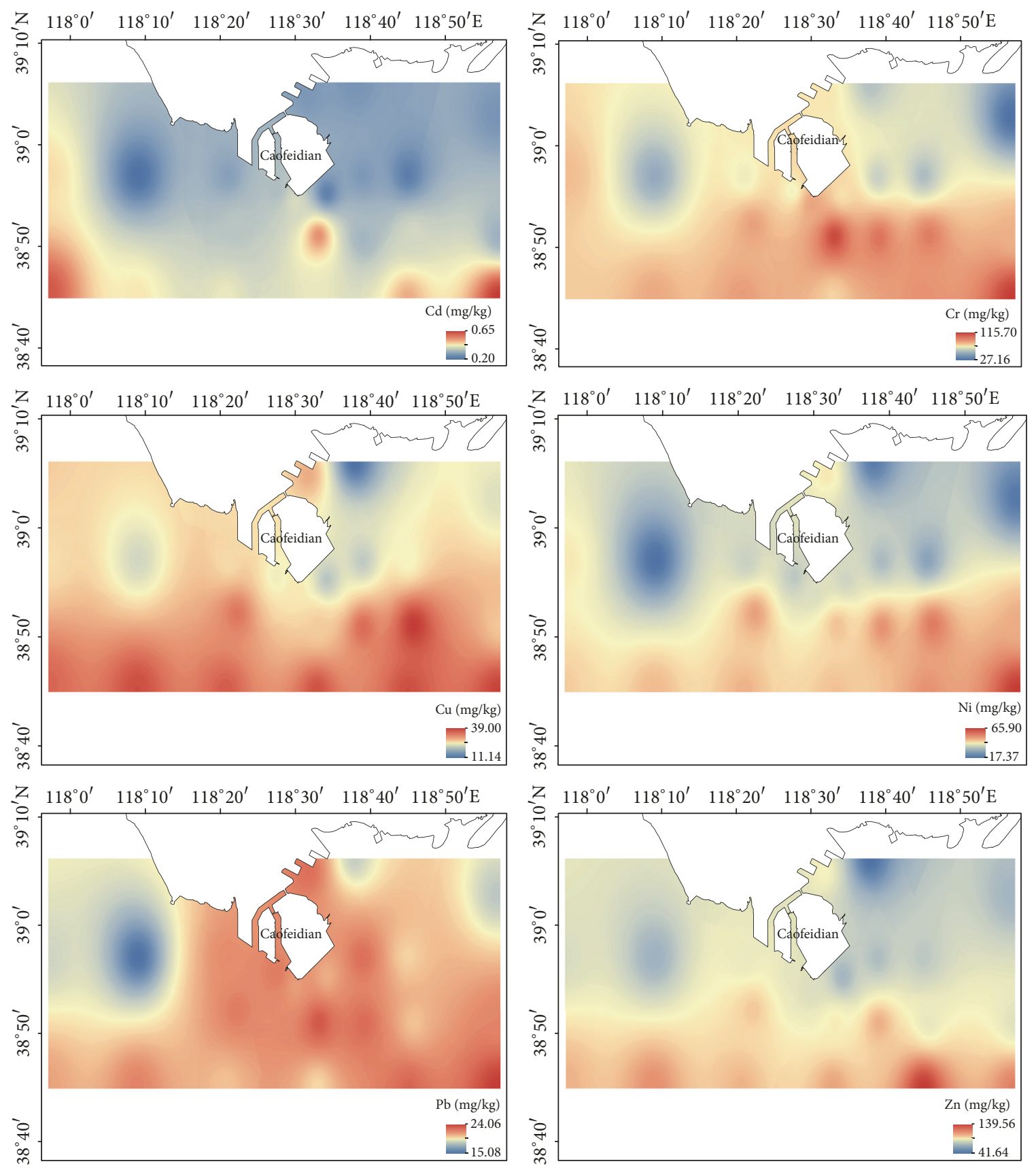

FIgURE 3: The spatial distribution of heavy metals in the sediments.

$[52,53]$. As a result, the concentrations of $\mathrm{Cu}$ and $\mathrm{Zn}$ in the sediment showed the higher values in the western Caofeidian and the central Bohai Bay than in the Laolonggou and the cape of Caofeidian. However, other heavy metals did not show significant relationships with the fine particles, which indicated that other factors determined their distribution in the sediments.

Organic matters and Fe/Mn oxides/hydroxides were considered as the controlling factors in the spatial distribution of heavy metals in the sediments. Organic matters can regulate the geochemical behavior of heavy metals via adsorption, desorption, and complexation [54]. In our study, $\mathrm{Cd}, \mathrm{Cr}, \mathrm{Cu}$,
$\mathrm{Ni}$, and $\mathrm{Zn}$ in the sediments showed a significant positive correlation with TOC $(p<0.05$, Table 3$)$, which indicated that the adsorption and/or complexation of the organic matters might control the distribution of these metals in the sediments. However, there was a clear spatial difference of the distribution between TOC and heavy metals in the western Caofeidian. This indicated that organic matters were not the major controlling factor in the distribution of the heavy metals in this area. The Fe/Mn oxides/hydroxides coated on clay minerals or in individual minerals are important carriers of heavy metals. In this study, the heavy metals in the sediments correlated significantly with Fe and $\mathrm{Mn}(p<0.01$, 


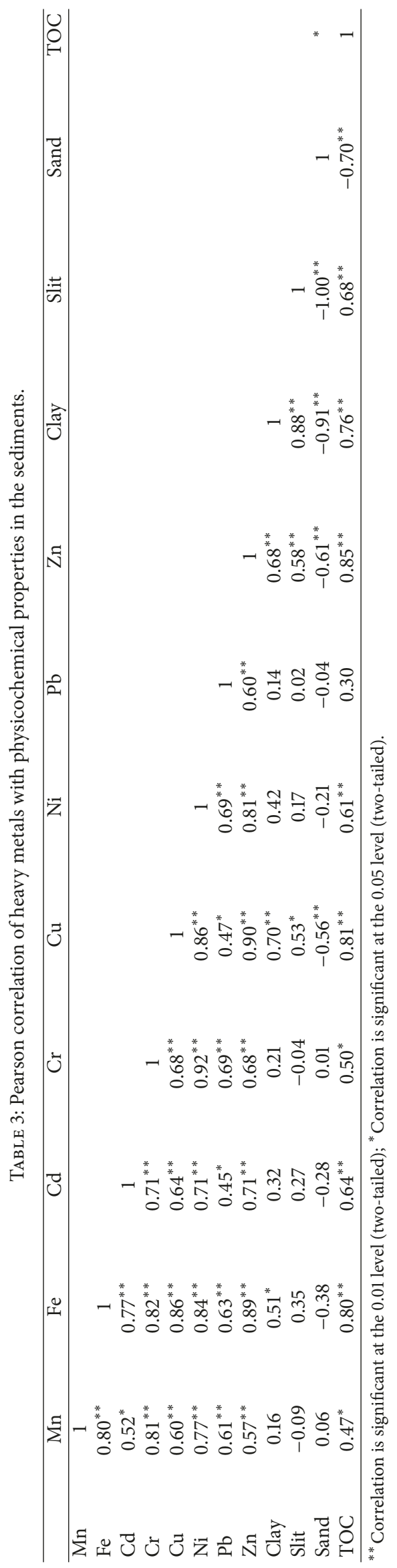


Table 3), and spatially the distribution of heavy metals was in agreement with that of $\mathrm{Fe}$ and $\mathrm{Mn}$. This indicated that the Fe/Mn oxides/hydroxides played an important role in the distribution of heavy metals, especially in the western Caofeidian.

As shown in Figure 3, the distribution of $\mathrm{Pb}$ in the sediments was different from that of other heavy metals. Besides the factors of hydrodynamic conditions and $\mathrm{Fe} / \mathrm{Mn}$ oxides/ hydroxides, the accumulation of $\mathrm{Pb}$ in the sediments could be attributed to its sources. In the coastal area of Caofeidian, the ancient Luanhe River alluvium contains a high geological background of $\mathrm{Pb}$ [55]. Thus, the erosion of land materials may be a reason for the different distribution of $\mathrm{Pb}$ from other metals in the sediments. Moreover, the Luanhe River is the main input river to the Caofeidian areas, and the concentration of $\mathrm{Pb}$ in the sediments of Luanhe River was higher than that in other rivers surrounding Bohai Bay (Table 2). This is why the concentration of $\mathrm{Pb}$ was markedly higher in the sediments of eastern Caofeidian (Figure 3). In addition, a large number of steel and chemical plants and the Caofeidian Port were established after the land reclamation of Caofeidian. The industrial emissions from electroplating materials and paint coatings for corrosion protection as well as shipping contaminants further induced the complex distribution of $\mathrm{Pb}$ in the sediments [56].

\subsection{Contamination and Risk Assessment of \\ Heavy Metals in the Sediments}

3.4.1. Contamination Assessment of Heavy Metals. Sediment quality guidelines (SQGs) have been widely applied to assess the metal contamination levels in sediments. The contamination states of heavy metals in the study area were determined by comparing the metal levels in the sediments of the Chinese Marine Sediment Quality (GB 18668-2002) [30] and the TEL/PEL SQGs $[53,54]$ (Table 2). The results showed that the concentrations of $\mathrm{Cd}, \mathrm{Pb}$, and $\mathrm{Zn}$ in the sediments were blew Class 1 accounted for $100 \%$ of the total sampling sites. There were $54.5 \%$ and $31.8 \%$ sampling sites with the concentrations of $\mathrm{Cr}$ and $\mathrm{Cu}$ varying Class 1 and Class 2 . According to the TEL and PEL, the adverse biological effect cannot occur when the concentrations of heavy metals are below the TEL, but it may emerge if the values reach the PEL $[28,57]$. Our results showed that the concentrations of $\mathrm{Cd}, \mathrm{Cr}, \mathrm{Cu}, \mathrm{Ni}, \mathrm{Pb}$, and $\mathrm{Zn}$ in the sediments below the TEL accounted for $100 \%$, $18.2 \%, 4.6 \%, 0 \%, 100 \%$, and $9.1 \%$ of the total sampling sites, respectively. There were $81.8 \%, 95.5 \% 40.9 \%$, and $90.9 \%$ of the sampling sites with the concentrations of $\mathrm{Cr}, \mathrm{Cu}, \mathrm{Ni}$, and $\mathrm{Zn}$ varying between the TEL and PEL, suggesting occasional toxic to the ecosystem by these metals. In addition, $59.1 \%$ of the sampling sites showed the $\mathrm{Ni}$ concentrations exceeding the TEL (Table 4).

The EF > 1.5 commonly indicates a marked enrichment of heavy metals in the sediments $[1,28]$. As shown in Table 4 , the EF of Cd were higher than 2.5 with the average of 3.44 suggesting a clear contamination in the sediments, whereas the sediments were not contaminated by $\mathrm{Cu}$ with its $\mathrm{EF}$ of $0.75-1.46$. The EF values of $\mathrm{Cr}$ and $\mathrm{Ni}$ were higher than 1.5 but lower than 3.0, which generally showed a low contamination level. The $\mathrm{EF}$ values of $\mathrm{Pb}$ and $\mathrm{Zn}$ indicated that the sediments were slightly contaminated by $\mathrm{Pb}$ and $\mathrm{Zn}$. Similar to the results of EF (Table 4), the $I_{\text {geo }}$ values also showed that the $\mathrm{Cd}$ in the sediments of most of the study areas was in the moderate to heavy contamination level, $\mathrm{Cr}$ and $\mathrm{Ni}$ generally showed the uncontaminated to moderately contaminated level, and $\mathrm{Cu}, \mathrm{Pb}$, and $\mathrm{Zn}$ were in the uncontaminated level. Spatially, the distribution of heavy metal contamination in the sediments was in agreement with the distribution of their concentrations (Figure 3).

3.4.2. Risk Assessment of Heavy Metals. According to the Hakanson potential ecorisk index (Table 4), the potential ecorisk of $\mathrm{Cd}$ in the sediments was in a high level (65.45-212.75, average: 118.80). Other heavy metals in the sediments showed a very low ecorisk level (less than 10), suggesting their low potential ecorisk to marine biome. Moreover, the RI varied between 77.93 and 236.83 with the average of 137.29 , and Cd accounted for $86.5 \%$ of the RI, suggesting $\mathrm{Cd}$ as the main metal for the sediment safety due to its high toxicity. Based on the RI, $36.4 \%$ of the sampling sites presented the moderate ecorisk level.

The index of $\sum$ TUs is used to assess the toxic effect of heavy metals in sediments, since it enables the comparison of the potential toxicity among various sediments based on chemical models [58]. In our study, $\sum$ TUs of heavy metals in the sediments were below 4.0 indicating no toxicity to the marine organisms. Spatially, $\sum$ TUs of the heavy metals in the sediments were higher in the central Bohai Bay than in the Caofeidian areas (Figure 4). The TU of an individual metal decreased in the order of $\mathrm{Ni}(0.97)>\mathrm{Cr}(0.49)>\mathrm{Zn}(0.33)$ $>\mathrm{Cu}(0.27)>\mathrm{Pb}(0.19)>\mathrm{Cd}(0.09)$, and the average contribution of each metal to the $\sum$ TUs was $41.4 \%$ for Ni, $21.1 \%$ for $\mathrm{Cr}, 14.2 \%$ for $\mathrm{Zn}, 11.5 \%$ for $\mathrm{Cu}, 8.1 \%$ for $\mathrm{Pb}$, and $3.7 \%$ for $\mathrm{Cd}$. Although the EF and $I_{\text {geo }}$ of $\mathrm{Cd}$ in the sediments were the highest among the heavy metals, its contribution to the $\sum$ TUs was the least. This suggested that the high contamination of Cd must not induce toxicity to the marine biome, and the volumes or contents of $\mathrm{Cd}$ have to be considered, especially its bioavailable forms.

The TRI considering the TEL and PEL was applied to assess the toxic risk of heavy metals in the sediments to marine organisms (Figure 4). The results showed that the TRI of heavy metals in the sediments varied between 3.08 and 8.25 with the average of 5.6 , and $31.8 \%$ of the sites in the Caofeidian area were in the nontoxic level and $68.2 \%$ of the sites in the central Bohai Bay were in the low toxic level. The average contribution of each metal to the TRI was $34.7 \%$ for Ni, $19.8 \%$ for $\mathrm{Cr}, 19.7 \%$ for $\mathrm{Cu}, 9.9 \%$ for $\mathrm{Zn}, 9.1 \%$ for $\mathrm{Pb}$, and $6.7 \%$ for $\mathrm{Cd}$, which revealed $\mathrm{Ni}$ as the main metal contributing to the sediment toxicity.

3.5. Implication of the Land Reclamation of Caofeidian for the Heavy Metal Contamination. Land reclamation for agriculture or harbor can cause a series of environmental issues. For example, Bai et al. found that the concentrations of heavy metals in the sediments of Pearl River Estuary increased with the reclamation time [59]. Rahman and Ishiga reported that marine sediments became significantly contaminated by 


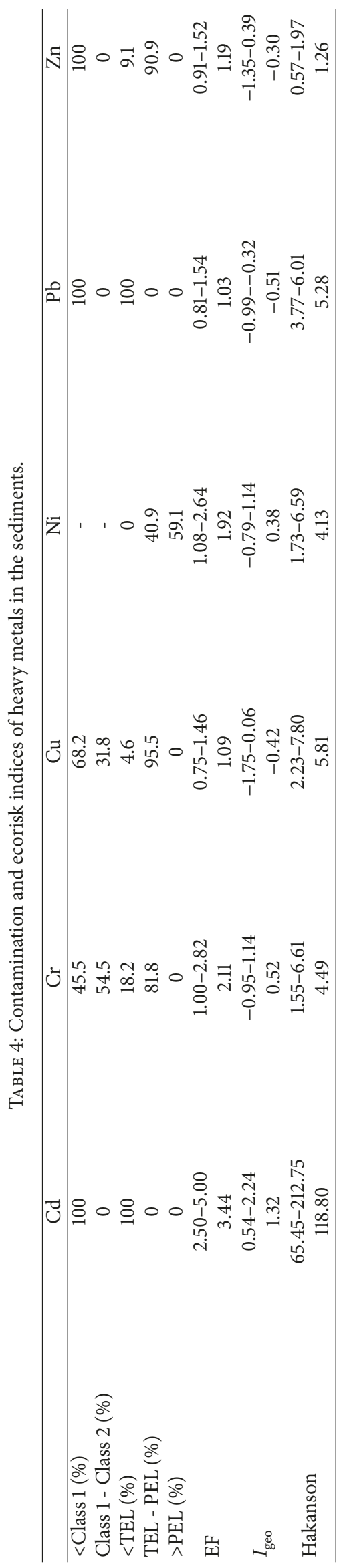



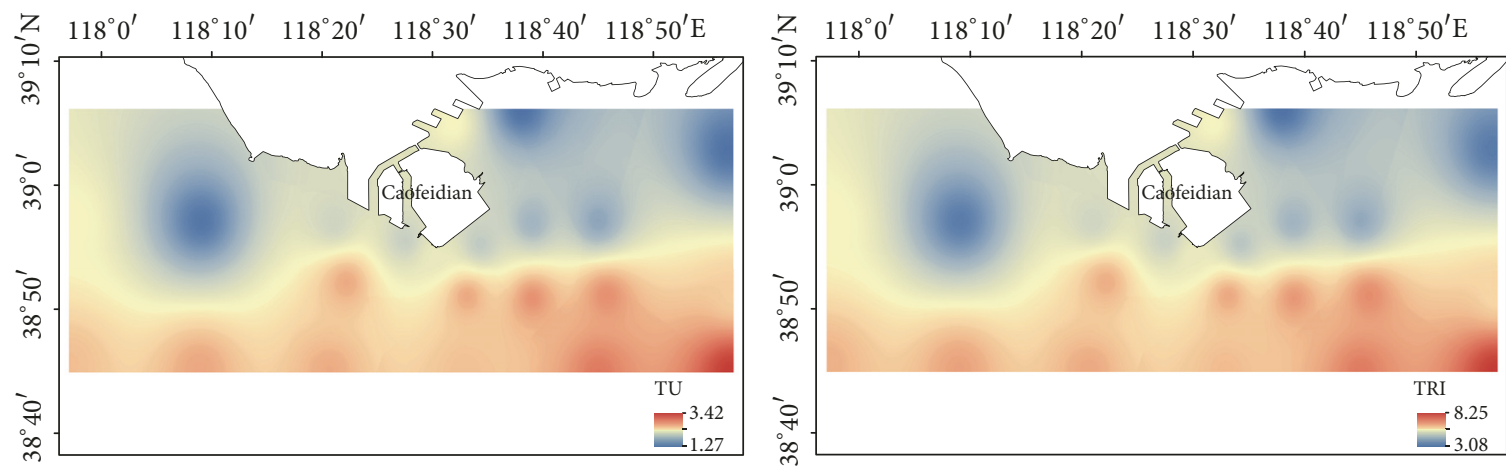

FIgURE 4: The spatial distribution of the TUs and TRI of heavy metals in the sediments.

heavy metals in the coastal region near the urban areas and harbors of Japan [60]. The study of Xiao et al. revealed the wetland reclamation elevated the accumulation of heavy metals in the soils of Cixi [61]. Zhang et al. found that the reclamation processes in coastal areas resulted in serious contamination of heavy metals to the aquatic ecosystem of Pearl River Estuary [62]. All the studies above showed the land reclamation had negative effects on the aquatic ecosystems. However, according to the spatial distribution of the concentrations, contamination, and ecorisk indices of heavy metals in the sediments of our study area (Figures 3 and 4 ), the reclamation project of Caofeidian did not induce the markedly high contamination and ecorisk of heavy metals in the sediments. In contrast, the low contamination level of heavy metals in the sediments of Laolonggou and the cape of Caofeidian was clearly observed. This was mainly related to the way of the project and its effect on the hydrodynamic conditions [24]. Whether the accumulation of heavy metals in the sediments increases after the land reclamation project of Caofeidian still needs to be explored in future.

\section{Conclusions}

The concentrations of heavy metals were generally higher in the sediments of Caofeidian area than of other Chinese bays and estuaries. The markedly lower concentrations of $\mathrm{Cd}, \mathrm{Cr}$, $\mathrm{Cu}, \mathrm{Ni}$, and $\mathrm{Zn}$ in the sediments existed surrounding the land of Caofeidian compared with other regions, whereas those of $\mathrm{Pb}$ was markedly higher in the inshore areas of Caofeidian and the central Bohai Bay. Hydrodynamic conditions were the major factors affecting the distribution of heavy metals. The composition of grain sizes determined the distribution of $\mathrm{Cu}$ and $\mathrm{Zn}$ in the sediments, and organic matters and Fe/Mn oxides/hydroxides also controlled the distribution of heavy metals. The inshore sediments were moderately contaminated by $\mathrm{Cd}$, whereas they were uncontaminated or uncontaminated to moderately contaminated by other metals. Similarly, Cd showed a high potential risk in the sediments, and other metals were in the low risk level. Chromium was a main metal that contributed to the exposure toxicity.

\section{Data Availability}

The data used to support the findings of this study are available from the corresponding author upon request.

\section{Conflicts of Interest}

The authors declare that they have no conflicts of interest.

\section{Acknowledgments}

This study was financially supported by the National Nature Science Foundation of China (no. 41371104) and the Youth Innovation Promotion Association Fund, Chinese Academy of Science.

\section{References}

[1] A. Armid, R. Shinjo, A. Zaeni, A. Sani, and R. Ruslan, "The distribution of heavy metals including $\mathrm{Pb}, \mathrm{Cd}$ and $\mathrm{Cr}$ in Kendari Bay surficial sediments," Marine Pollution Bulletin, vol. 84, no. 1-2, pp. 373-378, 2014.

[2] C. Christophoridis, D. Dedepsidis, and K. Fytianos, "Occurrence and distribution of selected heavy metals in the surface sediments of Thermaikos Gulf, N. Greece. Assessment using pollution indicators," Journal of Hazardous Materials, vol. 168, no. 2-3, pp. 1082-1091, 2009.

[3] F. Kucuksezgin, E. Uluturhan, and H. Batki, "Distribution of heavy metals in water, particulate matter and sediments of Gediz River (Eastern Aegean)," Environmental Modeling \& Assessment, vol. 141, no. 1-3, pp. 213-225, 2008.

[4] Y. Kara and A. Zeytunluoglu, "Bioaccumulation of toxic metals (Cd and $\mathrm{Cu}$ ) by Groenlandia densa (L.) Fourr.”, Bulletin of Environmental Contamination and Toxicology, vol. 79, no. 6, pp. 609-612, 2007.

[5] H. Gan, J. Lin, K. Liang, and Z. Xia, "Selected trace metals (As, $\mathrm{Cd}$ and $\mathrm{Hg}$ ) distribution and contamination in the coastal wetland sediment of the northern Beibu Gulf, South China Sea," Marine Pollution Bulletin, vol. 66, no. 1-2, pp. 252-258, 2013.

[6] B. Hu, R. Cui, J. Li et al., "Occurrence and distribution of heavy metals in surface sediments of the Changhua River Estuary and adjacent shelf (Hainan Island)," Marine Pollution Bulletin, vol. 76, no. 1-2, pp. 400-405, 2013.

[7] B. Hu, J. Li, J. Zhao, J. Yang, F. Bai, and Y. Dou, "Heavy metal in surface sediments of the Liaodong Bay, Bohai Sea: distribution, contamination, and sources," Environmental Monitoring \& Assessment, vol. 185, no. 6, pp. 5071-5083, 2013.

[8] M. Baborowski, O. Büttner, P. Morgenstern, T. Jancke, and B. Westrich, "Spatial variability of metal pollution in groyne fields 
of the Middle Elbe - Implications for sediment monitoring," Environmental Pollution, vol. 167, pp. 115-123, 2012.

[9] G. W. Bryan and W. J. Langston, "Bioavailability, accumulation and effects of heavy metals in sediments with special reference to United Kingdom estuaries," Environmental Pollution, vol. 76, no. 2, pp. 89-131, 1992.

[10] H. Bing, J. Zhou, Y. Wu, X. Wang, H. Sun, and R. Li, “Current state, sources, and potential risk of heavy metals in sediments of Three Gorges Reservoir, China," Environmental Pollution, vol. 214, pp. 485-496, 2016.

[11] F. Li, X.-Y. Zeng, C.-H. Wu et al., "Ecological risks assessment and pollution source identification of trace elements in contaminated sediments from the Pearl River Delta, China," Biological Trace Element Research, vol. 155, no. 2, pp. 301-313, 2013.

[12] A. Zahra, M. Z. Hashmi, R. N. Malik, and Z. Ahmed, "Enrichment and geo-accumulation of heavy metals and risk assessment of sediments of the Kurang Nallah-feeding tributary of the Rawal Lake Reservoir, Pakistan," Science of the Total Environment, vol. 470-471, pp. 925-933, 2014.

[13] J. Viers, B. Dupré, and J. Gaillardet, "Chemical composition of suspended sediments in World Rivers: New insights from a new database," Science of the Total Environment, vol. 407, no. 2, pp. 853-868, 2009.

[14] N. A. Hill, S. L. Simpson, and E. L. Johnston, "Beyond the bed: effects of metal contamination on recruitment to bedded sediments and overlying substrata," Environmental Pollution, vol. 173, pp. 182-191, 2013.

[15] H. Wang, J. Wang, R. Liu, W. Yu, and Z. Shen, "Spatial variation, environmental risk and biological hazard assessment of heavy metals in surface sediments of the Yangtze River estuary," Marine Pollution Bulletin, vol. 93, no. 1-2, pp. 250-258, 2015.

[16] J. Bai, Q. Zhao, Q. Lu, J. Wang, and K. R. Reddy, "Effects of freshwater input on trace element pollution in salt marsh soils of a typical coastal estuary, China," Journal of Hydrology, vol. 520, pp. 186-192, 2015.

[17] S. Rahmanpour, N. F. Ghorghani, and S. M. Lotfi Ashtiyani, "Heavy metal in water and aquatic organisms from different intertidal ecosystems, Persian Gulf," Environmental Modeling \& Assessment, vol. 186, no. 9, pp. 5401-5409, 2014.

[18] L. Wang, N. A. Coles, C. Wu, and J. Wu, "Spatial variability of heavy metals in the coastal soils under long-term reclamation," Estuarine, Coastal and Shelf Science, vol. 151, pp. 310-317, 2014.

[19] J. Bai, J. Jia, G. Zhang et al., "Spatial and temporal dynamics of heavy metal pollution and source identification in sediment cores from the short-term flooding riparian wetlands in a Chinese delta," Environmental Pollution, vol. 219, pp. 379-388, 2016.

[20] H. Bing, Y. Wu, E. Liu, and X. Yang, "Assessment of heavy metal enrichment and its human impact in lacustrine sediments from four lakes in the mid-low reaches of the Yangtze River, China," Journal of Environmental Sciences, vol. 25, no. 7, pp. 1300-1309, 2013.

[21] I. D. L. Foster and S. M. Charlesworth, "Heavy metals in the hydrological cycle: Trends and explanation," Hydrological Processes, vol. 10, no. 2, pp. 227-261, 1996.

[22] X. Wang, H. Bing, Y. Wu, J. Zhou, and H. Sun, "Distribution and potential eco-risk of chromium and nickel in sediments after impoundment of Three Gorges Reservoir, China," Human and Ecological Risk Assessment, vol. 23, no. 1, pp. 172-185, 2017.

[23] X. Gao and C.-T. A. Chen, "Heavy metal pollution status in surface sediments of the coastal Bohai Bay," Water Research, vol. 46, no. 6, pp. 1901-1911, 2012.
[24] Y. Lu, R. Ji, and L. Zuo, "Morphodynamic responses to the deep water harbor development in the Caofeidian sea area, China's Bohai Bay," Coastal Engineering Journal, vol. 56, no. 8, pp. 831843, 2009.

[25] Y. Zhang and X. Gao, "Rare earth elements in surface sediments of a marine coast under heavy anthropogenic influence: The Bohai Bay, China," Estuarine, Coastal and Shelf Science, vol. 164, pp. 86-93, 2015.

[26] L. Gao, Z. Wang, S. Li, and J. Chen, "Bioavailability and toxicity of trace metals $(\mathrm{Cd}, \mathrm{Cr}, \mathrm{Cu}, \mathrm{Ni}$, and $\mathrm{Zn})$ in sediment cores from the Shima River, South China," Chemosphere, vol. 192, pp. 31-42, 2018.

[27] Q. An, Y. Wu, J. Wang, and Z. Li, "Assessment of dissolved heavy metal in the Yangtze River estuary and its adjacent sea, China," Environmental Modeling \& Assessment, vol. 164, no. 1-4, pp. 173187, 2010.

[28] J. Liu, P. Yin, B. Chen, F. Gao, H. Song, and M. Li, "Distribution and contamination assessment of heavy metals in surface sediments of the Luanhe River Estuary, northwest of the Bohai Sea," Marine Pollution Bulletin, vol. 109, no. 1, pp. 633-639, 2016.

[29] CCME, Canadian sediments quality guidelines for the protection of aquatic life: summary tables. Canadian Environmental Quality Guidelines, Canadian Council of Ministers of the Environment Winnipeg, 1999.

[30] AQSIQ, "Administration of quality supervision, inspection and quarantine of the People's Republic of China," in Marine Sediment Quality of China (GB 18668-2002), p. 2, Standards Press of China, Beijing, China, 2002.

[31] C. C. M. Ip, X.-D. Li, G. Zhang, O. W. H. Wai, and Y.-S. Li, “Trace metal distribution in sediments of the Pearl River Estuary and the surrounding coastal area, South China," Environmental Pollution, vol. 147, no. 2, pp. 311-323, 2007.

[32] X. Li, O. W. H. Wai, Y. S. Li, B. J. Coles, M. H. Ramsey, and I. Thornton, "Heavy metal distribution in sediment profiles of the Pearl River estuary, South China," Applied Geochemistry, vol. 15, no. 5, pp. 567-581, 2000.

[33] G. Muller, "Index of geoaccumulation in sediments of the Rhine River," Geojournal, vol. 2, no. 108, pp. 108-118, 1969.

[34] F.-L. Li, C.-Q. Liu, Y.-G. Yang, X.-Y. Bi, T.-Z. Liu, and Z.-Q. Zhao, "Natural and anthropogenic lead in soils and vegetables around Guiyang city, southwest China: A Pb isotopic approach," Science of the Total Environment, vol. 431, pp. 339-347, 2012.

[35] F. Xu, B. Hu, S. Yuan et al., "Heavy metals in surface sediments of the continental shelf of the South Yellow Sea and East China Sea: Sources, distribution and contamination," Catena, vol. 160, pp. 194-200, 2018.

[36] L. Hakanson, "An ecological risk index for aquatic pollution control. A sedimentological approach," Water Research, vol. 14, no. 8, pp. 975-1001, 1980.

[37] M. Liu, A. Zhang, Y. Liao, B. Chen, and D. Fan, “The environment quality of heavy metals in sediments from the central Bohai Sea," Marine Pollution Bulletin, vol. 100, no. 1, pp. 534543, 2015.

[38] Z. Xie, H. Zhang, X. Zhao, Z. Du, L. Xiang, and W. Wang, "Assessment of Heavy Metal Contamination and Wetland Management in a Newly Created Coastal Natural Reserve, China," Journal of Coastal Research, vol. 32, no. 2, pp. 374-386, 2016.

[39] Z. Sun, X. Mou, C. Tong et al., "Spatial variations and bioaccumulation of heavy metals in intertidal zone of the Yellow River estuary, China," Catena, vol. 126, pp. 43-52, 2015. 
[40] G. Wu, J. Shang, L. Pan, and Z. Wang, "Heavy metals in surface sediments from nine estuaries along the coast of Bohai Bay, Northern China," Marine Pollution Bulletin, vol. 82, no. 1-2, pp. 194-200, 2014.

[41] X. Gao and P. Li, "Concentration and fractionation of trace metals in surface sediments of intertidal Bohai Bay, China," Marine Pollution Bulletin, vol. 64, no. 8, pp. 1529-1536, 2012.

[42] X. Gao, Y. Yang, and C. Wang, "Geochemistry of organic carbon and nitrogen in surface sediments of coastal Bohai Bay inferred from their ratios and stable isotopic signatures," Marine Pollution Bulletin, vol. 64, no. 6, pp. 1148-1155, 2012.

[43] C.-P. Kuang, S.-Y. Chen, Y. Zhang et al., "A two-dimensional morphological model based on next generation circulation solver II: Application to Caofeidian, Bohai Bay, China," Coastal Engineering Journal, vol. 59, no. 1, pp. 14-27, 2012.

[44] G. Xu, J. Liu, S. Pei, M. Gao, G. Hu, and X. Kong, "Sediment properties and trace metal pollution assessment in surface sediments of the Laizhou Bay, China," Environmental Science and Pollution Research, vol. 22, no. 15, pp. 11634-11647, 2015.

[45] D. Han, J. Cheng, X. Hu et al., "Spatial distribution, risk assessment and source identification of heavy metals in sediments of the Yangtze River Estuary, China," Marine Pollution Bulletin, vol. 115, no. 1-2, pp. 141-148, 2017.

[46] S. R. Taylor and S. M. McLennan, "The chemical composition evolution of the continental crust," Reviews of Geophysics, vol. 33, no. 2, pp. 241-265, 1995.

[47] D. D. Macdonald, R. S. Carr, F. D. Calder, E. R. Long, and C. G. Ingersoll, "Development and evaluation of sediment quality guidelines for Florida coastal waters," Ecotoxicology, vol. 5, no. 4, pp. 253-278, 1996.

[48] F. Pedersen, E. Bjørnestad, H. V. Andersen, J. Kjølholt, and C. Poll, "Characterization of sediments from Copenhagen Harbour by use of biotests," Water Science and Technology, vol. 37, no. 6-7, pp. 233-240, 1998.

[49] Y.-J. Lu, L.-Q. Zuo, R.-Y. Ji, X. Xu, and J.-W. Huang, "Effect of development of Caofeidian harbor area in Bohai bay on hydrodynamic sediment environment," China Ocean Engineering, vol. 22, no. 1, pp. 97-112, 2008.

[50] Y. Dou, J. Li, J. Zhao, B. Hu, and S. Yang, "Distribution, enrichment and source of heavy metals in surface sediments of the eastern Beibu Bay, South China Sea," Marine Pollution Bulletin, vol. 67, no. 1-2, pp. 137-145, 2013.

[51] R. Xiao, M. Zhang, X. Yao, Z. Ma, F. Yu, and J. Bai, "Heavy metal distribution in different soil aggregate size classes from restored brackish marsh, oil exploitation zone, and tidal mud flat of the Yellow River Delta," Journal of Soils and Sediments, vol. 16, no. 3, pp. 821-830, 2016.

[52] S. L. Yang and H. F. Yang, "Temporal Variations in Water and Sediment Discharge from the Changjiang (Yangtze River) and Downstream Sedimentary Responses," in Ecological Continuum from the Changjiang (Yangtze River) Watersheds to the East China Sea Continental Margin, Estuaries of the World, pp. 71-91, Springer International Publishing, 2015.

[53] J. Bai, R. Xiao, K. Zhang, and H. Gao, "Arsenic and heavy metal pollution in wetland soils from tidal freshwater and salt marshes before and after the flow-sediment regulation regime in the Yellow River Delta, China," Journal of Hydrology, vol. 450-451, pp. 244-253, 2012.

[54] J. C. Santos Bermejo, R. Beltrán, and J. L. Gömez Ariza, “Spatial variations of heavy metals contamination in sediments from Odiel river (Southwest Spain)," Environment International, vol. 29, no. 1, pp. 69-77, 2003.
[55] J. Zhang, "Biogeochemistry of Chinese estuarine and coastal waters: Nutrients, Trace metals and biomarkers," Journal of Material Cycles and Waste Management, vol. 3, no. 1-3, pp. 6576, 2002.

[56] R. A. Sutherland, "Bed sediment-associated trace metals in an urban stream, Oahu, Hawaii," Environmental Geology, vol. 39, no. 6, pp. 611-627, 2000.

[57] E. R. Long, L. J. Field, and D. D. Macdonald, "Predicting toxicity in marine sediments with numerical sediment quality guidelines," Environmental Toxicology \& Chemistry, vol. 17, no. 4, pp. 714-727, 2010.

[58] G. Zhang, J. Bai, Q. Zhao, Q. Lu, J. Jia, and X. Wen, "Heavy metals in wetland soils along a wetland-forming chronosequence in the Yellow River Delta of China: Levels, sources and toxic risks," Ecological Indicators, vol. 69, pp. 331-339, 2016.

[59] J. Bai, R. Xiao, B. Cui et al., "Assessment of heavy metal pollution in wetland soils from the young and old reclaimed regions in the Pearl River Estuary, South China," Environmental Pollution, vol. 159, no. 3, pp. 817-824, 2011.

[60] M. A. Rahman and H. Ishiga, "Trace metal concentrations in tidal flat coastal sediments, Yamaguchi Prefecture, southwest Japan," Environmental Modeling \& Assessment, vol. 184, no. 9, pp. 5755-5771, 2012.

[61] R. Xiao, J. Bai, Q. Lu et al., "Fractionation, transfer, and ecological risks of heavy metals in riparian and ditch wetlands across a 100-year chronosequence of reclamation in an estuary of China," Science of the Total Environment, vol. 517, pp. 66-75, 2015.

[62] G. Zhang, J. Bai, R. Xiao et al., "Heavy metal fractions and ecological risk assessment in sediments from urban, rural and reclamation-affected rivers of the Pearl River Estuary, China," Chemosphere, vol. 184, pp. 278-288, 2017. 

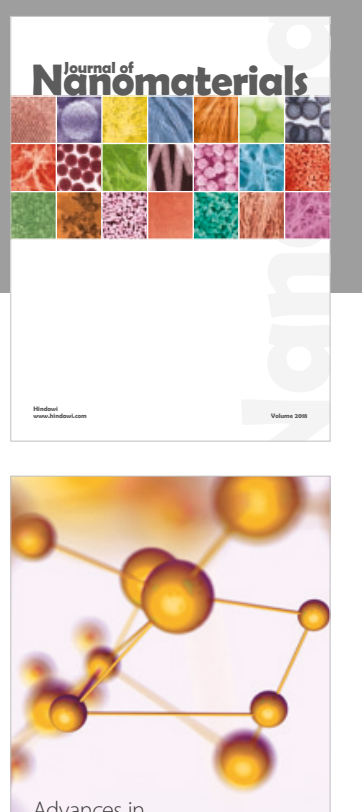

Physical Chemistry
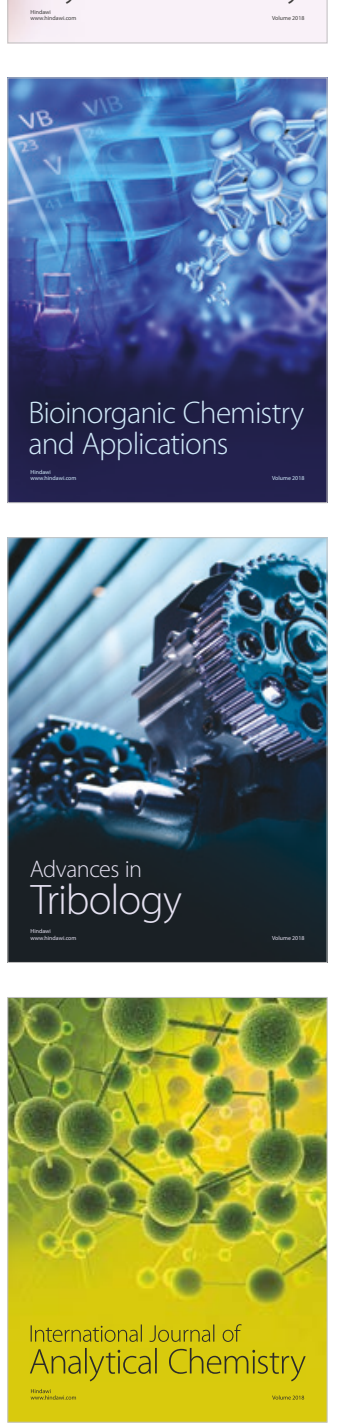

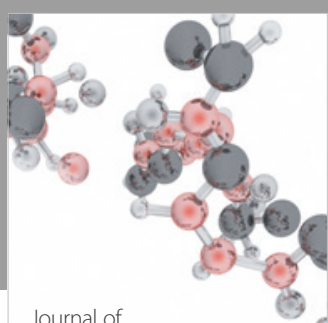

Analytical Methods

in Chemistry

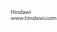

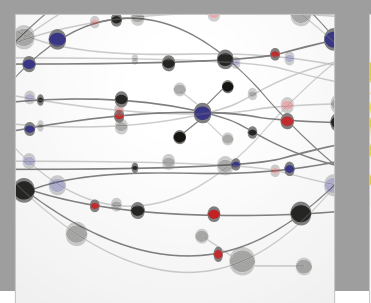

The Scientific World Journal

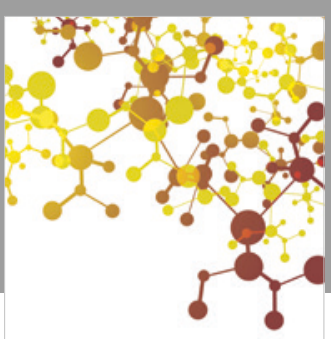

Journal of

Applied Chemistry
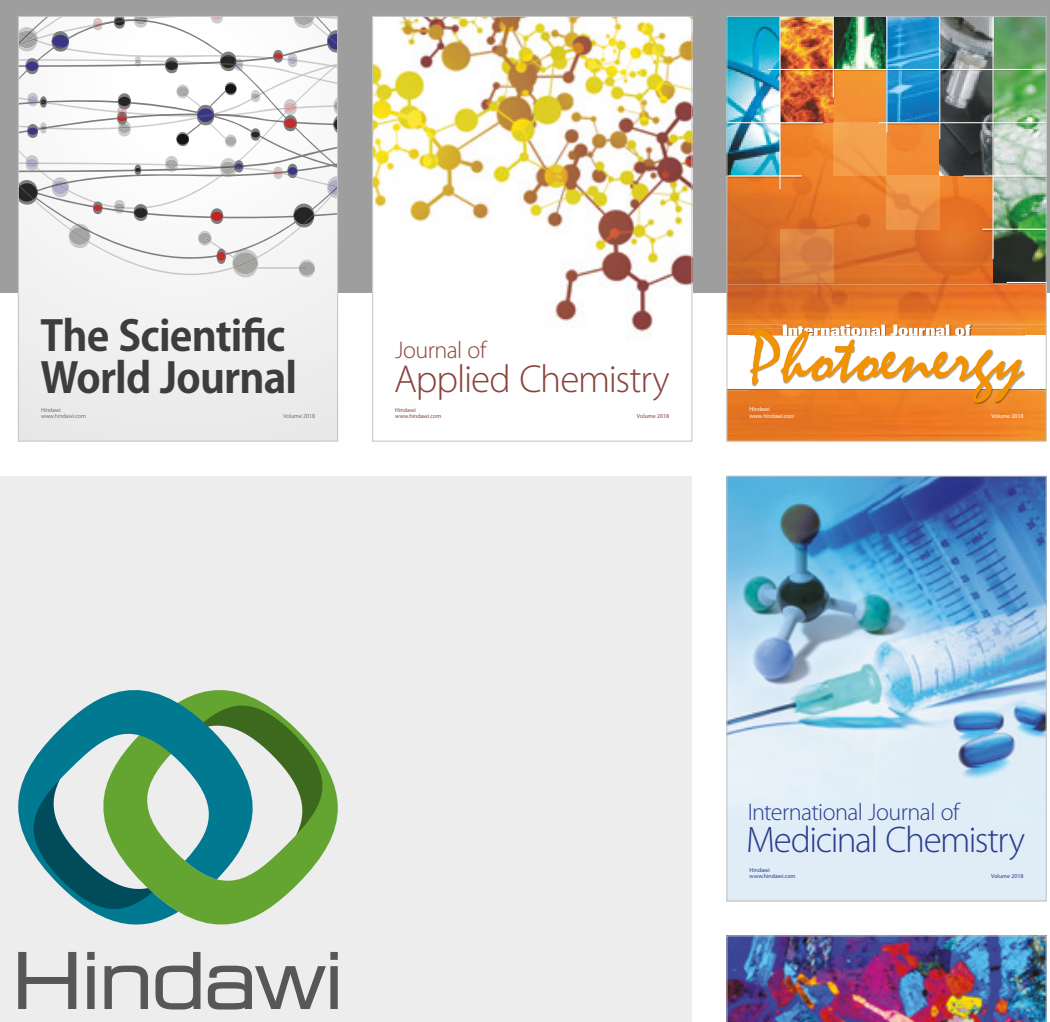

Submit your manuscripts at

www.hindawi.com
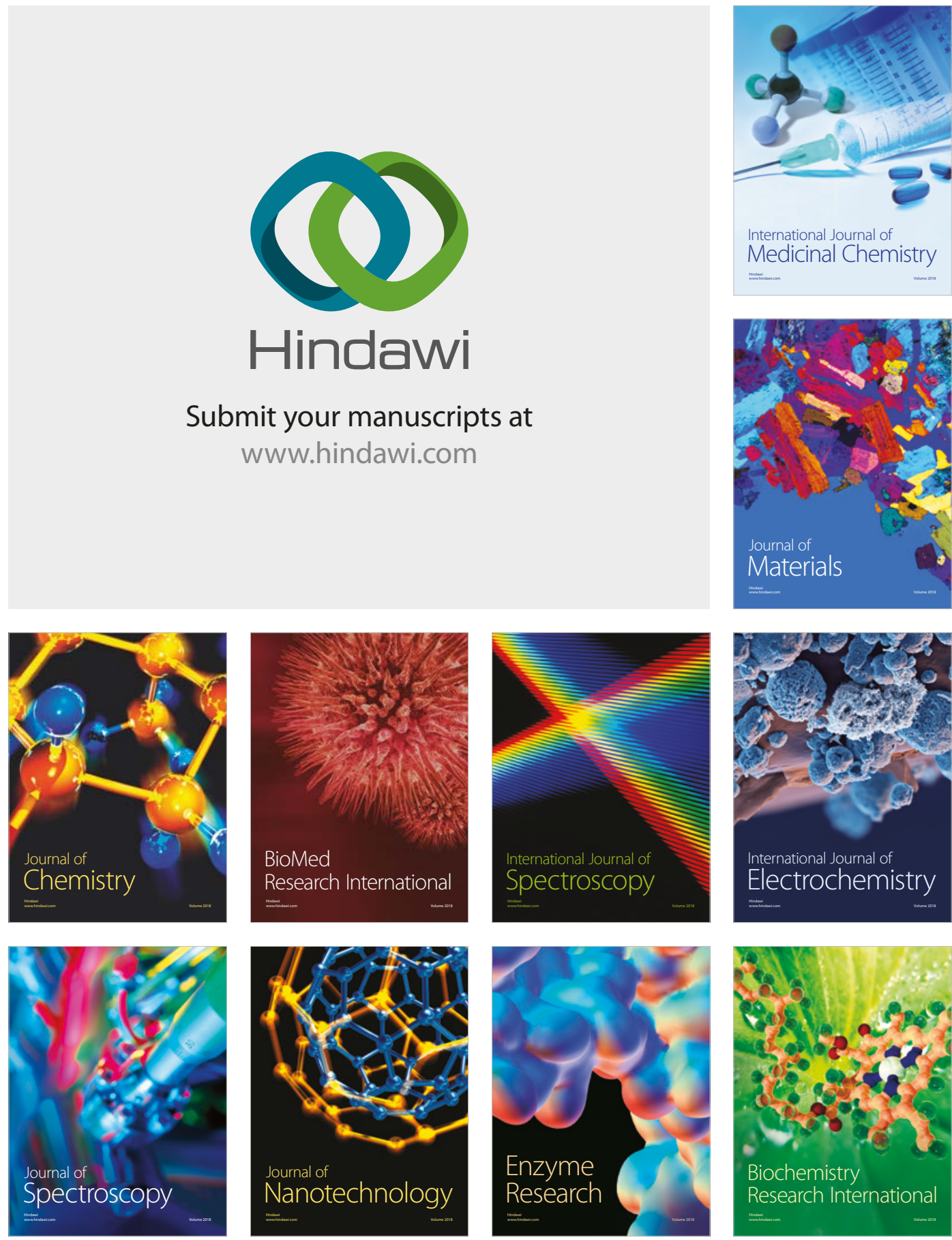
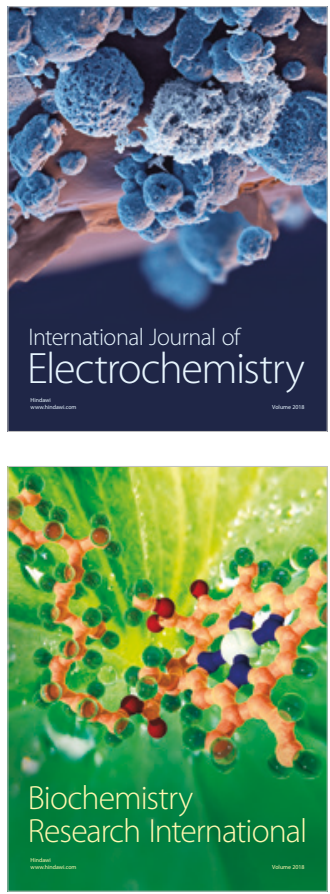